Polgári Szemle, 16. éuf. 4-6. szám, 2020, 279-284., DOI: 10.24307/psz.2020.1020

Banyár József

\title{
A feleslegesre van pénzünk, a szükségesre pedig nincs idônk? Hozzászólás Árva László és Várhelyi Tamás Elmozdulás a minôségi turizmus felé címú tanulmányához
}

\author{
Do We Have Money for What Is \\ Unnecessary and No Time for What Is \\ Necessary?
}

\author{
Comment on the Study Entitled Towards High Quality \\ Tourism by László Árva and Tamás Várhelyi
}

\section{ÖSSZEFOGLALÁS}

Ahogy Árva László és Vásárhelyi Tamás cikkükben (Árva-Várhelyi, 2020) a turizmussal kapcsolatban megfogalmazták, manapság a marketing nagyon sok felesleges igényt generál. Hozzászólásomban ennek okát keresem, s azt találom, hogy ennek legfontosabb oka a feleslegesen hosszú munkaidó. Az így megkeresett jövedelmen pedig egyre több lényegében felesleges - terméket és szolgáltatást fogunk megvásárolni. Ezekre ráadásul - bizonyos mértékig - rá is szorulunk, mert nem marad időnk másfajta igények kielégítésére, aminek az egész társadalomra és gazda- ságra nézve súlyos következményei vannak. Az egyik legfontosabb ilyen a gyermeknevelés.

Journal of Economic Literature (JEL) kódok: M3, N3, J13

Kulcsszavak: munkaidô-csökkentés, szabadidô, felesleges igények

\section{SUMMARY}

As László Árva and Tamás Vásárhelyi put in their article in relation to tourism, nowadays marketing generates a great deal of unnecessary demand. Looking for the underlying reasons, this study finds that one of the causes

Dr. Banyár József PhD, egyetemi docens, Budapesti Corvinus Egyetem (jozsef.banyar@uni-corvinus.hu). 


\section{Tudományos múhely}

is the unnecessarily long working time. People use the income earned to buy an increasing number of - actually unnecessary products and services. In addition, to some extent we are need them because no time is left for satisfying demands of other kinds, and this has serious consequences for the entire society and economy. One of the most important such demands is raising children.

Journal of Economic Literature (JEL) codes: M3, N3, J13

Keywords: reduction of working time, leisure time, unnecessary requirements

\section{Bevezetés}

Árva László és Várhelyi Tamás minôségi turizmusról szóló tanulmányát (Árva-Várhelyi, 2020) áthatja a felesleges, marketing által generált igények elleni fellépés, az ettôl való megszabadulás szükségessége. Én magam a turizmushoz nem értek, de ez a gondolat sokkal általánosabb, a gazdaság és az élet alapvetố dimenzióit érintố problémára tapint rá, amit ezért érdemes alaposabban szemügyre venni. Az alábbiakban röviden és hangsúlyozottan vázlatosan ennek az általános problémakörnek néhány nagyon fontos okát és következményét próbálom felderíteni. Állításaim:

- A felesleges szükségletek gerjesztése részben az elosztás problémáiban, részben viszont a fejlett világ felesleges termelókapacitásaiban gyökerezik, ami pedig a túlzottan magas egy fốre esố munkaidőre vezethetô vissza.

- A túlzottan magas munkaidố kiszorítja az ember igényei és lehetôségei közül a minốségi nem munkaidôs tevékenységeket, elsôsorban a gyermekvállalást, $\mathrm{s}$ helyére a bóvlit nyújtja, amit a felesleges munkaidôben állít elố a gazdaság.

\section{A TúLzotT MUNKAIDó GENEZISE}

Munkaidố alatt hangsúlyozottan egy formális munkahelyen töltött idôt értek. Ha nem ezt érteném, akkor igaz lenne az az állítás, hogy a fejlődéssel egyre csökken az egy ember által munkában töltött idố (ezt fogalmazza meg pl. Mihályi, 2012). Látszólag ez a formális munkahelyen töltött idôre is vonatkozik, hiszen az ipari forradalom idején még heti hat napban, napi 12-14 órát dolgoztak a munkások, ez fokozatosan lecsökkent napi 8 órára. ${ }^{1}$ Azután erôsen lefékezôdött a csökkenés, pedig Keynes 1930-ban azt jósolta, hogy a munkaidô napi három órára csökken 2030-ra (idôarányosan messze járunk ettôl); idóközben a hat nap lecsökkent ötre, illetve egyre hosszabb lett a garantált éves szabadság is. Azért nevezem ezt látszólagos csökkenésnek, mert lakosságarányosan egy före vetítve mindezen csökkenés ellenére az elôzô évszázadban nagy növekedés ment végbe, ugyanis egyre nôtt a dolgozó nốk aránya (ráadásul egyre csökkent - mint majd alább kifejtem, ettől nem függetlenül - a szintén a „nevezóben” szerepló gyermekek száma is, melyet valamelyest mérsékelt a nyugdíjasok növekvố száma). Vagyis míg nagyjából száz évvel ezelōtt családonként az egy dolgozó apa és egy (otthon igen, de formális munkahelyen) nem dolgozó anya, illetve 3-4 gyermek volt a jellemzô, mára a két dolgozó szülő és a másfél gyermek. Tehát hiába csökkent a formális munkaidô hossza azoknak, akik munkahelyen dolgoznak, ha a társadalom sokkal nagyobb része dolgozik ilyen helyen. Ez másképp azt jelenti, hogy sokkal kevesebb idô jut azokra a tevékenységekre, amelyeket régen nem a munkahelyen végzett el a család. Emellett persze erôteljesen növekedett az életszínvonal, de úgy túnik, hogy ennek az életszínvonalnak egy jelentôs része már nem a valódi szükségletek kielégítését szolgálja. ${ }^{2}$

A nốk munkába állását a két világháború ösztönözte, amikor is a háborúzó férfiakat egyre inkább nôkkel kellett pótolni. Ez persze megmutatta, hogy nốk egyrészt alkalmasak a legtöbb, korábban csak férfiak által végzett munkára, másrészt azt is, hogy szeretnek dolgozni, élvezik az önálló keresetet s az ezzel megnyílt gazdasági önállóságot, 


\section{Tudományos múhely}

sôt szeretik magukat továbbképezni stb. A világháborúk alapvetôen elszegényedést hoztak világszerte, amelynek leküzdése, a korábban megszokott életszínvonal helyreállítása többletmunkát, a társadalmi munkaidóbázis növelését igényelte, vagyis a nôk fokozatos munkába állását.

A nôk munkába állása viszont azután sem csökkent, hogy az életszínvonal helyreállt, sôt dinamikusan emelkedett, hiszen megváltozott a férfiak és a nôk közti, korábban megszokott munkamegosztás. Viszont a munkaidóbázis ezen a megnövekedett szinten maradt, vagyis a társadalom hatalmas termelőkapacitást alakított ki, ami a tehetetlenség törvénye miatt úgy is maradt. ${ }^{3} \mathrm{Ez}$ pedig átalakította mind az emberek igényeit, mind a lehetôségeit.

KÖVETKEZMÉNYEK: FELESLEGES IGÉNYEK GERJESZTÉSE, A GYERMEKNEVELÉS

ELHANYAGOLÁSA

Mindennek két fơ következménye lett: 1) az egyéneknek és a családoknak sokkal kevesebb lehetôségük maradt olyasmivel foglalkozni, amihez idôre lenne szükség, mert a korábban erre szánt családi idôt is elfoglalta a munkaidő; 2) ugyanakkor rengeteg plusz anyagi forrás keletkezett az egyéneknél és a családoknál is, amelyet olyasmire lehet költeni, amit készen meg lehet venni.

Azoknak a családi tevékenységeknek egy részét, amelyekre hajdan a munkahelyeken kívüli idôt fordították (fôzés, takarítás, mosás stb.), részben kiváltották a megnövelt társadalmi munkaidôben elôállított - és az ezért járó megnövelt bérból megvásárolható - háztartási gépekkel és tömegessé váló étkeztetési szolgáltatásokkal. De nem minden korábbi tevékenységet lehetett megvásárolható termékekkel kiváltani. A legfontosabb ilyen tevékenység a gyermeknevelés, amely fóleg intenzív személyes figyelmet és évekig állandó személyes jelenlétet igényel. Természetesen itt is megjelentek fizetett szolgáltatások, fóleg az óvoda, ugyanakkor a legkisebbeknek szóló bölcsôde nem igazán vált be. Az eredmény - nem csoda - az egy családra jutó gyermekek számának fokozatos és egyre radikálisabb csökkenése lett. ${ }^{4}$ Ez ráadásul a maga részérôl - mivel annak nemcsak idő-, hanem anyagi vonzata is van - újabb, fogyasztásra elkölthetô forrásokat hagyott az egyéneknél, relatíve tovább növelve a második következmény hatását.

Itt állunk tehát, kevés szabadidôvel, de relatíve sok, készen kapható fogyasztási cikkre elköthető jövedelemmel, miközben szemmel láthatólag - egyre kevésbé találunk értelmes fogyasztási célokat. Érdemes megemlíteni még egy dolgot, ami relatíve független az elôzôektôl: az utóbbi 3-4 évtizedben világszerte egyre egyenlőtlenebbé vált a jövedelmek elosztása, ami azt jelenti, hogy a felső nagyjából 20\% pluszjövedelmeként jelent meg ezen időszak gazdasági növekedésének nagyobbik része, vagyis rájuk még inkább igaz, hogy „nem tudják mire költeni a pénzüket”. A maradék $80 \%$ szempontjából valamivel egyszerúbb a probléma: ôk az esetleges pluszjövedelmeiket könnyebben el tudnák költeni, akár értelmesen is, mégpedig a 20\% által már „bejáratott”, de számukra még anyagilag nem elérhető javakra.

Ez persze nemcsak a fogyasztó oldaláról jelentkezô probléma, hanem a termelés, vagyis a vállalatok részéról is. Náluk ugyanis adott a nagy termelési kapacitás, de problémaként merül fel, hogy mit is állítsanak eló, ha a fizetôképes rétegek részérôl már minden értelmes igényt kielégítettek, a nem fizetôképesek értelmes igényeit pedig nem racionális kielégíteni. Egy ilyen helyzetben logikus megoldás lenne a termelési kapacitás csökkentése, de a verseny logikája ezt nem teszi lehetôvé. (Egy logikailag hasonló, de más területrôl vett példa: a magyar felsôoktatás kapacitása jóval nagyobb, mint amire értelmes igény lenne. Csökkenteni kellene azt, vagyis bezárni, illetve összevonni létesítményeket. De ezt önmaguktól az egyes intézmények nem teszik meg, inkább megindul a verseny a hallgatókért, aminek egyik módszere a felvételi követelmények csökkentése, majd a számonkérés színvo- 


\section{Tudományos múhely}

nalának rontása - végsố soron a diplomák értékének devalválása.)

A verseny logikája, vagyis az az elv, hogy minden egyes konkrét szereplő csak a saját érdekeit nézi, nem az egészét (ami persze természetes, az utóbbi nem az ô dolga, szemben az elôbbivel), nem erre visz, hanem arra, hogy megpróbáljanak új, megvásárolható termékekkel és szolgáltatásokkal kielégíthetố igényeket kreálni, s ezeket erôs marketinges technikákkal megismertetni a potenciális fogyasztókkal. Az erôs marketing pedig, amellett, hogy a szerzốk által leírt mesterségesen gerjesztett igényekkel újabb termékeknek és szolgáltatásoknak teremt piacot, vagyis tovább múködteti a megnövelt termelési kapacitást, a maga részérôl ebbő́l a megnövelt kapacitásból szintén nagyon nagy részt köt le, hiszen a marketingrészlegek rengeteg és egyre növekvô számú embert foglalkoztatnak - miközben száz éve ilyen részlegek szinte nem is léteztek. Tehát maga a marketing két oldalról is segít lekötve tartani a feleslegesen nagy termelési kapacitást, amit leginkább a magas egy fớre jutó formális munkaidôvel mérhetünk.

\section{MEgOLdÁS: MUNKAIDŐ-CSÖKKENTÉS ÉS AZ ELOSZTÁs „ROTÁCIÓJA”}

A megoldás alapvetôen a szabályozó kezében van: csökkenteni a feleslegesen nagy termelési kapacitást, a feleslegesen nagy munkaidóbázist, vagyis a munkaidôt. Ezáltal részben kevesebb tere lenne a felesleges igények felkeltésének, részben az emberek is el tudnák magukat foglalni olyan tevékenységekkel, amelyekhez idô kell. Az ilyen szabályozást persze leginkább a legfejlettebb országokban kell kezdeni, a felesleges fogyasztás ott a legnagyobb probléma. Ehelyett sokszor az az érzése az embernek, hogy az államok nem az ilyen szabályozásban jeleskednek, hanem az olyanokban, amelyek megnövelik a felesleges adminisztrációt, vagyis a maguk részérôl segítenek feladatot adni a felesleges munkaerónek vagyis inkább abban „segítenek”, hogy ne kelljen leépíteni a túlzottan magas munkaidôbázist.

Társadalmi szempontból a legnagyobb jelentôségú „szabadidôs tevékenység” a gyermeknevelés lenne, egy ilyen munkaidő-csökkentô szabályozással újra megnövekedne a családok gyermekekre fordítható ideje, mint volt az hajdan. Természetesen az új körülmények között ez már nem fóleg a nô dolga lenne, hanem az apa és anya közös vállalkozása.

Fontos persze megjegyezni, hogy - ilyen elôzmények után - a megnövelt szabadidó nem mindenkinél vezetne el több gyerek vállalásához, ahhoz másra is szükség van, de az biztos, hogy az alap, hogy az embereknek újra legyen ehhez elég ideje. Ezért (is) a szabályozónak - ha esetleg rászánja magát a munkaidố csökkentésére - jól át kell gondolnia, hogy azt hogyan teszi, hiszen sokfajta munkaidôbázis-csökkentés lehetséges, és mindegyik mást tesz lehetôvé, illetve másra ösztönöz. Lehetséges az éves szabadság növelése, lehetséges a négynapos munkahét bevezetése ${ }^{5}$ - változatlan nyolcórás munkaidôvel -, és lehetséges a napi munkaidố csökkentése. A gyermeknevelés szempontjából - mivel az nem kampányszerú, hanem folyamatos tevékenység - ez utóbbi a leginkább célszerú. (Érdekes, hogy 90 éve Keynes maga is a napi munkaidốt csökkentette volna, nem a munkahét hosszát. ${ }^{6}$ ) Az pedig, hogy a megnövekedett szabadidôt az állam leginkább a gyermeknevelésre fordított idô növelésére szeretné fordíttatni, esetleg úgy „kommunikálható”, hogy a munkaidốt elôször - változatlan bér mellett (esetleg úgy, hogy azt az állam maga pótolja ki, pl. a személyi jövedelemadó elengedésével) - a gyermeket nevelóknél csökkenti, s csak fokozatosan terjeszti ki azt mindenkire.

A munkaidó csökkentése - szintén csak akkor, ha az okos politikával társul, amely ráveszi, illetve megtanítja az embereket a napi mozgás kultúrájára - az egészségi állapot népességszintú javulásának az előmozdítója is lehet, hiszen az embereknek így több idejük lenne az egészségükkel foglalkozni, illetve 


\section{Tudományos múhely}

sportolni. Ez azt is jelentené, hogy csökkenhetnének, illetve minôségileg átstrukturálódhatnának az egészségügyi kiadások, s az emberek a munkában kevésbé használódnának el, s így tovább tudnának dolgozni, vagyis növelni lehetne a nyugdíjkorhatárt. ${ }^{7}$ A nagyobb gyermekszám mellett ez egy másik fontos tényezó, amely egy, a mainál fenntarthatóbb nyugdíjrendszert eredményezne.

Végezetül röviden kitérnék még egy tényezốre, amire fentebb már utaltam. Akkor sem kell felesleges új igényeket teremteni, ha a jövedelemelosztást némileg kiegyenlítettebbé tesszük. Erre a „rotálás” szót alkalmazhatjuk, hiszen ha lerajzolnánk, hogy a különbözô jövedelmi rétegekhez az adott ország éves jövedelmének mekkora hányada tartozik, akkor erôsen növekvố görbét kapnánk. A „rotálás”, vagyis elforgatás arra utal, mintha középen kicsit „megcsavarnánk” ezt a görbét, s ennek hatására felül az csökkenne, alul pedig növekedne. A felsôbb jövedelmi dekádoktól az alsóbbakhoz juttatott jövedelemnek jóval kevésbé kell keresni az értelmes elköltési lehetôségét, hiszen már ott vannak a felsôbb rétegek által „kikísérletezett” fogyasztási cikkek, fogyasztási formák, amelyek előállítására ráadásul már jól kiépített gyártási kapacitások állnak rendelkezésre, nem kell különösebben felkelteni irántuk az igényt. S ezzel egyben rá is tudunk mutatni a jövedelmi egyenloótlenség egy pozitív funkciójára is (a negatívakról már esett szó): ez lehetôvé teszi az innovációt, hiszen vannak olyan rétegek, amelyek kísérleti, még nem kiforrott és még nagyon drága fogyasztási cikkeket is megvesznek, s visszajelzéseikkel segítenek azokat tökéletesíteni, s végül tömegtermékké tenni.

Összességében a munkaidố csökkentése lehetôvé tenné, hogy az embereket ahelyett, hogy felesleges dolgokat vesznek, „felszabadítaná” ez alól a munka alól, ami lehetôvé és „szükségletté” teszi számukra a felesleges igények kielégítését. A nagyobb szabadidô pedig lehetôvé tenné számukra, hogy maguk találjanak ki maguknak új szükségleteket a több szabadidejükben (tanuljanak, sportoljanak, találjanak ki kreatív hobbikat stb.). Ezzel valószínúleg újabb adag emberi kreativitást szabadítanánk fel, azt ugyanis mindig a több szabadidố táplálja. Ezzel pedig növeljük azt a tudást, amely mellett új, értelmes szükségletek keletkeznek, s felesleges lesz felesleges szükségleteket kreálni. És persze a legfontosabb: újra lenne idô gyermeket nevelni!

\section{JEGYZETEK}

1 Habár, ahogy az antropológusok megállapították, nem ez a „normális” emberi munkaidő, hiszen kezdetben vadászó-gyújtögetô eleink kb. napi 4 órát dolgoztak (Sahlins, é. n.), csak a földmûvelésre való áttéréssel lett egyre hosszabb a munkaidô. Az EU országainak aktuális átlagos munkaidejérôl és a szabadságokról lásd Eurofound, 2019.

2 Csatlós Hanna (2020) cikkében megemlíti, hogy „David Frayne, a The Refusal of Work. The Theory and Practice of Resistance to Work címú kötet szerzôje már a jelenkor interjúalanyaival beszélgetve figyelte azt meg, hogy ha kevesebbet dolgozunk, akkor még úgy is kevesebb pénzt költünk, hogy ha egyébként a bevételeink nem csökkennek radikálisan. Ha ugyanis több idônk van, akkor kevésbé költekezünk meggondolatlanul, és nem igényeljük, hogy intenzív fogyasztással, örömöt okozó vásárlásokkal kompenzáljuk a fáradtságos munkaórákat”. A hivatkozott könyv: Frayne, 2015.

3 Annak ellenére, hogy egyre többen vetik fel, hogy értelmes munkát is egyre nehezebb találni, s egyre nô az „alibimunkák” mennyisége, ahogyan azt David Graeber Bullshit Jobs címú, 2018as könyvében felveti (idézi Bugyinszki, 2020).

4 A gyermekszám csökkenésének nem ez az egyetlen oka. Egy másik nagyon fontos ok a rosszul kitalált modern nyugdíjrendszer. Lásd errôl Banyár-Németh (szerk.), (2020) tanulmányait. Arról, hogy ez ellen mit érdemes tenni, lásd pl. Banyár, 2019.

5 Ezt egyre többen követelik, illetve fejtik ki, hogy ez a termelékenység szempontjából is pozitív lépés lenne. Lásd pl. Taylor, 2019. Én viszont alapvetôen a napi munkaidô csökkentésének a hasznosságát húznám alá, illetve javasolnám a heti munkanapok csökkentése helyett.

${ }_{6}$ Keynes cikkére Edward és Robert Skidelsky (apa és fia; az apa neves Keynes-kutató) irányította rá 


\section{Tudományos múhely}

a figyelmet, magyarul 2014-ben megjelent könyvével, amely több kérdést hasonlóan tárgyal, mint ez a cikk.

7 A nyugdíjkorhatár indexálásáról lásd Banyár, 2020a; 2020b.

8 Köszönet a kifejezésért kollégámnak, Vékás Péternek, aki egyébként más értelemben használja azt (Vékás, 2019).

\section{FELHASZNÁLT IRODALOM}

Árva László - Várhelyi Tamás (2020): Elmozdulás a minôségi turizmus felé. A fenntarthatóság a turizmusban a koronavírusjárvány után. Polgári Szemle, 16. évf., 1-3. sz., 94-114, https://doi. org/10.24307/psz.2020.0707.

Banyár, József (2019): The Problems Underlying the Pension Scheme and Low Birth Rates Can Only Be Resolved Together. A Complex Proposal for Linking Pensions to Parenting. Polgári Szemle/Civic Review, Vol. 15, Special Issue, 289300, https://doi.org/10.24307/psz.2020.0216.

Banyár József (2020a): Miként javítható az állami nyugdíjrendszer? Öt lehetséges lépés egy átfogó reformhoz. Közgazdasági Szemle, 67. évf., 6. sz., 632652, https://doi.org/10.18414/ksz.2020.6.632.

Banyár József (2020b): Az idôsödés fogalmának egy lehetséges átdefiniálása és ennek implikációi. Az élettartam fokozatos növekedésébôl adódó kihívások a magyar tb nyugdíj alrendszerében - lehetséges válaszok. Biztositás és Kockázat, 7. évf., 3-4. sz., 28-38, https:// doi.org/10.18530/ BK.2020.3-4.28.

Banyár József - Németh György (szerk.) (2020): Nyugdí és gyermekvállalás 2.0. Nyugdíireform-elképzelések. Gondolat Kiadó, Budapest.

Bugyinszki György (2020): A munkahelyi alibizés már külön tudomány. Index.hu, https://index. hu/techtud/2020/09/20/a_munkahelyi_alibizes_mar_kulon_tudomany/.

Csatlós Hanna (2020): Tényleg sokkal kevesebbet kellene dolgoznunk, hogy nekünk és a környezetünknek is jó legyen? Hvg.hu, július. 29., https:// hvg.hu/elet/20200729_Sokkal_kevesebbet_kellene_dolgoznunk_hogy_nekunk_es_a_kornyezetunknek_is_jo_legyen.

Eurofound (2019): Working Time in 2017-2018. Publications Office of the European Union, Luxembourg, www.eurofound.europa.eu/sites/default/files/ef_publication/field_ef_document/ ef19030en.pdf.

Frayne, David (2015): The Refusal of Work. Rethinking Post-Work Theory and Practice of Resistance to Work. Zed Books Ltd. London.

Graeber, David (2018): Bullshit Jobs. A Theory. Simon and Schuster.

Keynes, John Maynard (1930): Economic Possibilities for our Grandchildren. www.econ.yale.edu/smith/ econ116a/keynes1.pdf.

Mihályi Péter (2012): Húsz érv a nyugdíj és a gyermekszám összekapcsolása ellen. In: Kovács Erzsébet (szerk.): Nyugdíj és gyermekvállalás. Tanulmánykötet 2012. Gondolat Kiadó, Budapest.

Sahlins, Marshall (é. n.): The Original Affluent Society. www.eco-action.org/dt/affluent.html.

Skidelsky, Edward - Skidelsky, Robert (2014): Menynyi az elég? A pénz imádata - Érvek a jó élet mellett. Corvina Kiadó, Budapest.

Taylor, Steve (2019): Less Hours for Work, More Time on Earth: Why a Four-day Working Week is Good for You. Independent, 16 December.

Vékás, Péter (2019): Rotation of the Age Pattern of Mortality Improvements in the European Union. Central European Journal of Operations Research, Vol. 28, No. 3, https://doi.org/10.1007/ s10100-019-00617-0. 